\title{
Diurnal variation in the response of anoestrous ewes to the ram effect
}

\author{
G. B. Martin*†, Y. Cognié†, A. Schirarł, A. Nunes-Ribeiro†, C. Fabre-Nys§ \\ and J.-C. Thiéry†
}

\author{
$\dagger$ I.N.R.A. and §C.N.R.S., Station de Physiologie de la Reproduction, 37380 Monnaie, France, and \\ $\ddagger$ I.N.R.A. Laboratoire de Physiologie de la Lactation, 78350 Jouy-en-Josas, France
}

\begin{abstract}
Summary. The re-introduction of rams after a period of separation was used to stimulate LH secretion and induce ovulation in seasonally anovulatory ewes maintained under natural photoperiod. In 2 experiments, the rams were introduced in the morning or the evening to test for diurnal variations in responsiveness to the treatment. In the first experiment, with Romanov ewes, the ram-induced increase in tonic LH secretion was significantly earlier in the ewes treated $(\mathrm{N}=6)$ at $07: 30 \mathrm{~h}$ (mean \pm s.e.m. delay to first pulse: $20 \pm 6 \mathrm{~min})$ than in those $(\mathrm{N}=5)$ treated at $19: 30 \mathrm{~h}(66 \pm 15 \mathrm{~min}$; $P=0.006$ ). The pulse interval after the ram effect was significantly shorter in ewes that subsequently ovulated $(120 \pm 10 \mathrm{~min})$ than in ewes that did not ovulate $(288 \pm 108$ min; $P=0.043$ ). There was a significant decline in pulse amplitude from $6.7 \pm 1.2$ to $3.4 \pm 0.6 \mathrm{ng} / \mathrm{ml}$ (both groups combined) after the introduction of $\operatorname{rams}(P=0.040)$. Of the 11 ewes, 7 subsequently ovulated and a preovulatory LH surge was observed in 6 of these $30-36 \mathrm{~h}$ after ram introduction.

In the second experiment, with seasonally anoestrous Préalpes-du-Sud ewes, the effect of the timing of the introduction of rams on the periovulatory events was tested. The delay to the onsets of oestrus and the LH surge was not affected, but the ovulation rate was higher after ram introduction in the morning (1.42) than in the evening (1.14).

In the 12-h period before the introduction of the rams in the first experiment, there was a difference between the groups in the secretion of $\mathrm{LH}$, but the existence of diurnal rhythms in the concentrations of LH or FSH were not confirmed in a later study in which 7 ewes were sampled every $20 \mathrm{~min}$ for $36 \mathrm{~h}$. In contrast, there was a distinct diurnal variation in the secretion of prolactin, with the highest values being recorded at night and the lowest around midday $(P=0 \cdot 025)$. The rise and fall in prolactin values did not appear to coincide with dawn or dusk.

It is concluded that: (1) the hypothalamic centres controlling tonic LH secretion are more responsive to the introduction of rams in the morning than in the evening, an effect which appears to be associated with an increased ovulatory response; (2) that anoestrous Romanov ewes will respond to the ram effect with an increased frequency of LH pulses which leads to ovulation; (3) that the increased pulse frequency is accompanied by a decrease in pulse amplitude; (4) that the pulse frequency attained after ram introduction determines whether the ewe will ovulate.
\end{abstract}

\section{Introduction}

Ewes in seasonal or post-partum anoestrus will respond to the introduction of rams with an increase in the tonic pulsatile secretions of $\mathrm{LH}$ and a preovulatory surge of LH and FSH. Most of

*Present address: MRC Reproductive Biology Unit, Centre for Reproductive Biology, 37 Chalmers Street, Edinburgh EH3 9EW, U.K. 
the ewes ovulate and continue to display regular oestrous cycles and this phenomenon, known as the 'ram effect', is now used by farmers in many areas of the world (reviews: Knight, 1983; Martin, 1984). However, comparison of the reports in the literature shows that it is rare for all ewes to respond fully, and that there is considerable variation between experiments and between flocks in the responsiveness of the ewes to the ram effect (Martin \& Scaramuzzi, 1983).

Daily rhythms in the secretion of melatonin, cortisol, growth hormone and prolactin have been described for the ewe (Davis \& Borger, 1974; Rollag \& Niswender, 1976; Fulkerson \& Tang, 1979; Walton, Evins, Fitzgerald \& Cunningham, 1980). There is also evidence for similar rhythms in the concentrations of luteinizing hormone ( $\mathrm{LH})$ and follicle-stimulating hormone (FSH) in rams (Lincoln \& Peet, 1977; Lincoln, Peet \& Cunningham, 1977; Ortavant et al., 1982). They have yet to be fully investigated in ewes, although we have observed that most ewes experience the onsets of oestrus and the LH surge at night (Fabre-Nys, Martin, Cognié \& Thiéry, 1984). Since diurnal rhythms affect the activity of the reproductive system, the response of ewes to the ram effect would depend on the phase of the rhythm during which the stimulus was applied, i.e. the time of day of the rams are introduced. This factor has not been taken into consideration in previous experiments.

In this article we describe experiments in which we studied the ram-induced responses in the secretion of $\mathrm{LH}$ in anoestrous ewes and tested the hypothesis that the timing of the introduction of rams determined the ovulatory and endocrine responses. We also studied the hormone concentrations in anoestrous ewes in detail and tested for diurnal variation in the secretion of LH, FSH and prolactin.

\section{Materials and Methods}

Since birth, the ewes had been maintained indoors in large pens under natural lighting through large windows. The experiments with Romanov ewes were carried out at Nouzilly in mid-June when the daylength was about $16 \mathrm{~h}$ and dawn was at $03: 50 \mathrm{~h}$. All manipulations at night were carried out with the aid of small, very faint lamps. The ewes were fed a mixture of hay $(800 \mathrm{~g} / \mathrm{head} /$ day), lucerne pellets $(300 \mathrm{~g} / \mathrm{head})$ and cereal grain $(400 \mathrm{~g} / \mathrm{head})$ between $07: 00$ and $08: 00 \mathrm{~h}$ daily. They had free access to water. Blood was sampled 3 times weekly and analysed for progesterone (Terqui \& Thimonier, 1974) to verify that the animals were anovulatory. This procedure was preferred to laparoscopy, the stress of which has been shown to disrupt the ram effect (Martin, Oldham \& Lindsay, 1980b).

Experiment 1 . Eleven Romanov ewes were randomly assigned to 2 groups to be introduced to rams at $07: 30 \mathrm{~h}$ (Group AM-1, N=6) or at 19:30 h (Group PM-1, N=5). They were isolated from rams for a period of 4 weeks before the start of the experiment. Blood samples $(5 \mathrm{ml})$ were taken by jugular venepuncture every 20 min between -12 and $+12 \mathrm{~h}$ relative to ram introduction (1 vasectomized Ramonov for each group, introduced midway between 2 consecutive 20-min samples) and then every $4 \mathrm{~h}$ until $+48 \mathrm{~h}$. The plasma was separated and stored at $-15^{\circ} \mathrm{C}$ until assayed. The ewes underwent laparoscopy (Oldham \& Lindsay, 1980) 3 and 6 days after the introduction of rams to identify the ewes with corpora lutea. The concentration of LH was measured in all samples, and the concentration of FSH was measured in all samples taken up to the time of ram introduction.

Experiment 2. Ewes of the Préalpes-du-Sud breed, which were part of a breeding programme at an INRA station at Brouessy (near Paris), were used. They were aged 16 months at the start of the experiment in April when they were allocated to two groups of equal mean bodyweight: those in Group AM-2 $(\mathrm{N}=25)$ were introduced to rams at $08: 00 \mathrm{~h}$ and those in Group PM-2 $(\mathrm{N}=24)$ at 20:00 h.

All ewes had intravaginal sponges containing $40 \mathrm{mg}$ fluorogestone acetate (Chronogest-40, Intervet SA, Ave Goxé, Angers, France) inserted 12 days before ram introduction, in the morning 
(Group AM-2) or the evening (Group PM-2), to ensure that the ewes that responded would show oestrous behaviour. The sponges were then withdrawn in the morning (Group AM-2) or the evening (Group PM-2) and at the same time 3 entire rams wearing aprons (to prevent insemination) were introduced. Blood samples were taken every $2 \mathrm{~h}$ from the withdrawal of sponges until $24 \mathrm{~h}$ after the ewes were first detected in oestrus. Plasma was separated and assayed for $\mathrm{LH}$. Beginning $12 \mathrm{~h}$ after sponge withdrawal, the ewes marked by the rams were noted every $4 \mathrm{~h}$ and the rams were replaced. The ewes underwent laparoscopy 9 days later to determine the proportion ovulating and the ovulation rate (ovulations per ewe ovulating).

Experiment 3. The 7 Romanov ewes had been continuously in the presence of rams for at least 6 months and this condition was maintained throughout this experiment. With the aid of indwelling jugular catheters inserted the previous day, blood was sampled every 20 min for $36 \mathrm{~h}$ beginning at 04:20 $\mathrm{h}$. The plasma was separated and stored at $-15^{\circ} \mathrm{C}$ until assayed for LH and FSH. Prolactin concentrations were also measured to estimate the integrity of the circadian rhythms of the ewes under these conditions.

Hormone assays. Concentrations of LH were measured in duplicate aliquants of $100 \mu \mathrm{l}$ plasma by a double-antibody radioimmunoassay as originally described by Pelletier, Kann, Dolais \& Rosselin (1968). The activity of the standard (M3 CNRS) was 1.8 i.u./mg NIH-LH-S1 (M. Jutisz, C.N.R.S., Gif-sur-Yvette, France), the lowest point on the standard curve that was outside the range of the zero replicates was $60 \mathrm{pg} /$ tube, and the non-specific binding was $<5 \%$. The withinassay coefficient of variation was $<10 \%$. The radioimmunoassay for FSH has been described in detail by Blanc \& Poirier (1979). We used duplicate $50 \mu$ l samples of plasma, preparation CNRS-FSH-P26 as a standard (activity 14 i.u./mg NIH-FSH-S3) and preparation HG-FSH-225-226 (36 i.u./mg NIH-FSH-S3) for the tracer. The limit of detection of the standard curve was $100 \mathrm{pg} /$ tube and the within-assay coefficient of variation was $10 \%$. Prolactin concentrations were measured with the assay described by Kann (1971). We used duplicate aliquants of $20 \mu \mathrm{l}$ plasma and the preparation NIH-P-S6 as a standard and tracer. The limit of detection was $0.3 \mathrm{ng} / \mathrm{ml}$ and the coefficient of variation (within assay) was $8 \%$. All of the samples for a given experiment were assayed for each hormone in a single assay with standard curves at both the beginning and end of the assay.

Data analysis. Pulses of $\mathrm{LH}$ were defined as described elsewhere (Martin, Scaramuzzi \& Henstridge, 1983). In brief: (1) both the increase and the subsequent decrease in concentration had to exceed the sum of the assay errors (coefficient of variation) appropriate for the concentrations at the onset and the peak of the pulse; (2) the increase had to occupy no more than two sampling intervals and the decline had to begin within two sampling intervals of attainment of the peak. Pulse amplitude was calculated by subtracting the concentration at the onset of the pulse from the peak concentration, and pulse interval was estimated as the time between successive peaks. There was generally more than 1 measure of both variables for each profile so a mean was calculated and used in the analysis of treatment effects. When fewer than 2 pulses were observed, the longest period without pulses was used as an (under) estimate of the real interval. The data from 1 ewe in Group AM-1 were omitted from the analysis of pulse amplitude because no pulses were observed during the sample period. The effects of treatment were tested for statistical significance by analysis of variance, using paired comparisons to test for the effect of rams or one-way analysis (model II) to test for the effects of pulse parameters before ram introduction on the responsiveness to the rams. The effects of treatments on ovulatory responses were tested by $\chi^{2}$. All of the statistical methods used are described by Sokal \& Rohlf (1969).

Neither prolactin nor FSH appeared to be secreted as regular pulses, but there were large shortterm fluctuations in concentration and wide variations between individual animals in the overall levels of both hormones. The data for each ewe were divided into 2-h periods, each consisting of 6 replicates (the individual 20-min samples) and the mean concentration was calculated for each of 
these periods. This figure was converted to a percentage of the overall mean for each ewe and the resulting data were then subjected to a two-way analysis of variance (fixed effect model) which is suitable for the analysis of data collected by repeated measures on the same animal (Sokal \& Rohlf, 1969). The FSH data of ewes in Exp. 1, up to the introduction of rams, were similarly analysed.

\section{Results}

\section{Experiment 1}

Before the introduction of rams there was some evidence of differences between the groups, i.e. between day and night, in the secretion of LH and FSH. The LH pulse amplitudes differed significantly between the groups $(P=0.046)$ and although there was also a difference between the pulse intervals, it was not statistically significant (Table 1). The mean \pm s.e.m. FSH value for all samples for all 11 ewes before the introduction of rams was $5 \cdot 1 \pm 0 \cdot 3 \mathrm{ng} / \mathrm{ml}$, and there was a wide degree of between-ewe variation (range: $3 \cdot 6-6.6 \mathrm{ng} / \mathrm{ml}$ ). The mean values of $\mathrm{FSH}$ were $4.7 \pm 0.3 \mathrm{ng} / \mathrm{ml}$ $(\mathrm{N}=6)$ for Group AM-1 and $5.5 \pm 0.4 \mathrm{ng} / \mathrm{ml}(\mathrm{N}=5)$ for Group PM-1. These were not significantly different. When the data for the two groups were plotted on a common time axis, it appeared that the concentrations of FSH fell below the mean by $5-7 \%$ during the morning and rose above it by a similar amount during the afternoon (data not shown). However, the differences between nadir and peak values were not significant for Group AM-1 (LSD 13.6\%) or Group PM-1 (LSD $13.3 \%$ ).

After the introduction of rams (Table 1) there was a significant decrease in LH pulse interval ( $P<0.001$, paired comparisons, all ewes) which was significantly $(P=0.043)$ greater for the 7 ewes that later ovulated than for the 4 that did not ovulate. The amplitudes of the pulses were also significantly reduced by the ram effect ( $P=0 \cdot 040$, paired comparison, all ewes), but there was no significant difference between the ewes that later ovulated and those that did not. The first pulse after ram introduction was later in Group PM-1 (66 $\pm 15 \mathrm{~min})$ than in Group AM-1 (20 $\pm 6 \mathrm{~min})$ $(P=0.006)$. For the ewes that ovulated, the mean delay in Group PM-1 was $65 \pm 19 \mathrm{~min}(\mathrm{~N}=4)$ while in Group AM-1 all of the ewes $(\mathrm{N}=3$ ) had begun their first pulse at the first sample, $10 \mathrm{~min}$ after initial contact with the rams.

Table 1. The effects of the introduction of rams at 07:30 h (Group AM-1) or 19:30 h (Group PM-1) on ovarian function and the secretion of LH in seasonally anoestrous Romanov ewes

\begin{tabular}{lccccc}
\hline & $\begin{array}{c}\text { Group } \\
\text { AM-1 }\end{array}$ & $\begin{array}{c}\text { Group } \\
\text { PM-1 }\end{array}$ & $\begin{array}{c}\text { Groups } \\
\text { AM-1+PM-1 }\end{array}$ & $\begin{array}{c}\text { Ovulating } \\
\text { ewes }\end{array}$ & $\begin{array}{c}\text { Ewes not } \\
\text { ovulating }\end{array}$ \\
\hline No. of ewes & 6 & 5 & 11 & 7 & 4 \\
Before rams & & & & & \\
$\quad$ Total pulses & 8 & 13 & 21 & 15 & 6 \\
Pulse interval (min) & $472 \pm 63$ & $374 \pm 36$ & $427 \pm 41$ & $397 \pm 32$ & $480 \pm 91$ \\
$\quad$ Pulse amplitude (ng/ml) & $9 \cdot 1 \pm 1 \cdot 4$ & $4 \cdot 3 \pm 1 \cdot 1$ & $6 \cdot 7 \pm 1 \cdot 2$ & $5 \cdot 9 \pm 1 \cdot 0$ & $8 \cdot 5 \pm 2 \cdot 8$ \\
After rams & & & & & \\
$\quad$ Delay to 1st pulse $(\mathrm{min})$ & $20 \pm 6$ & $66 \pm 15$ & & & \\
$\quad$ Total pulses & 31 & 28 & 59 & 45 & 14 \\
$\quad$ Pulse interval & $230 \pm 80$ & $123 \pm 10$ & $181 \pm 47$ & $120 \pm 10^{*}$ & $288 \pm 108^{*}$ \\
$\quad$ Pulse amplitude $(\mathrm{ng} / \mathrm{ml})$ & $3 \cdot 7 \pm 0 \cdot 9$ & $30 \cdot 7$ & $33 \cdot 3$ & & \\
Ewes ovulated & 3 & 4 & 7 & & \\
$\quad$ Ovulation rate & $2,2,2$ & $2,3,3,4$ & $2 \cdot 6 \pm 0 \cdot 3$ & & \\
\hline
\end{tabular}

Values are mean \pm s.e.m.

*The variance was proportional to the mean so the data were transformed logarithmically (ln) before analysis. The transformed means ( \pm s.e.m.) were $4.77 \pm 0.08$ and $5.45 \pm 0.30$ respectively. 

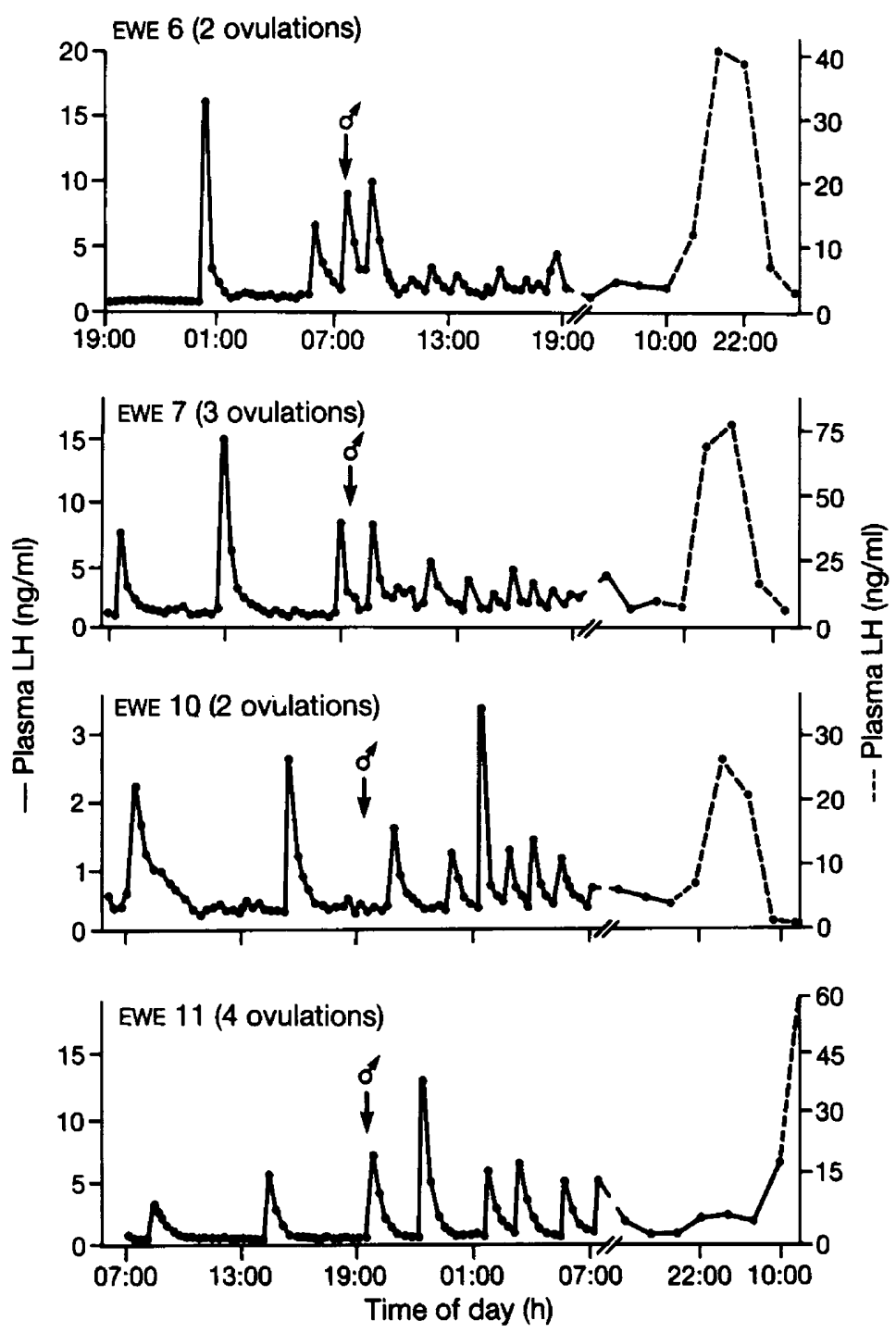

Text-fig. 1. The effect of the introduction of rams on the concentration of $\mathrm{LH}$ and ovulation in 4 anoestrous Romanov ewes which demonstrate the range of responses observed. The rams were placed with Ewe 6 in the morning and with the other ewes in the evening. Note the change in sampling frequency from once every $20 \mathrm{~min}$ in the first $24 \mathrm{~h}$ to once every $4 \mathrm{~h}$ towards the end of the observation period, and the higher concentration scale used to plot the preovulatory surge of LH (broken line).

In 6 of the 7 ovulating ewes, a preovulatory surge of LH was observed before the end of sampling (Text-fig. 1) within $48 \mathrm{~h}$ of the introduction of rams. The delay from the ram introduction to the surge was directly proportional to the pulse interval following the ram effect, but the correlation coefficient $(0.71)$ was not statistically significant. There were no significant relationships between the pulse interval before ram introduction and any of the responses observed. Apart from the effect on delay to the first pulse, ewes in Groups AM-1 and PM-1 responded similarly to the ram stimulus, there being no significant differences in the proportion of ewes ovulating, the pulse intervals, the ovulation rates or the delays to the $\mathrm{LH}$ surge. 


\section{Experiment 2}

The delays to the onset of oestrus and the LH surge, and the proportion of ewes ovulating (Table 2) were not affected by the time of ram introduction. However, the ewes in Group AM-2 had more multiple ovulations than did ewes in Group PM-2 $(P=0.069)$.

Table 2. Effect of time of ram introduction at 08:00 h (Group AM-2) or 20:00 h (Group PM-2) on periovulatory events in Préalpes-du-Sud ewes

\begin{tabular}{lccccccc}
\hline Group & $\begin{array}{c}\text { No. of } \\
\text { ewes }\end{array}$ & $\begin{array}{c}\text { Delay to } \\
\text { surge (h) }\end{array}$ & $\begin{array}{c}\text { Delay to } \\
\text { oestrus } \\
\text { (h) }\end{array}$ & $\begin{array}{c}\text { \% of ewes } \\
\text { ovulating }\end{array}$ & $\begin{array}{c}\text { Ovulation } \\
\text { rate }\end{array}$ & $\begin{array}{c}\text { Delay from } \\
\text { oestrus to } \\
\text { LH surge (h) }\end{array}$ & $\begin{array}{c}\text { \% ewes } \\
\text { marked }\end{array}$ \\
\hline AM-2 & 25 & $40 \cdot 0 \pm 2 \cdot 0$ & $41 \cdot 4 \pm 2 \cdot 2$ & 96 & 1.42 & $-2.9 \pm 1 \cdot 6$ & 84 \\
PM-2 & 24 & $40.8 \pm 1 \cdot 8$ & $40.2 \pm 1.4$ & 96 & $1 \cdot 14$ & $+0.7 \pm 1 \cdot 4$ & 87 \\
\hline
\end{tabular}

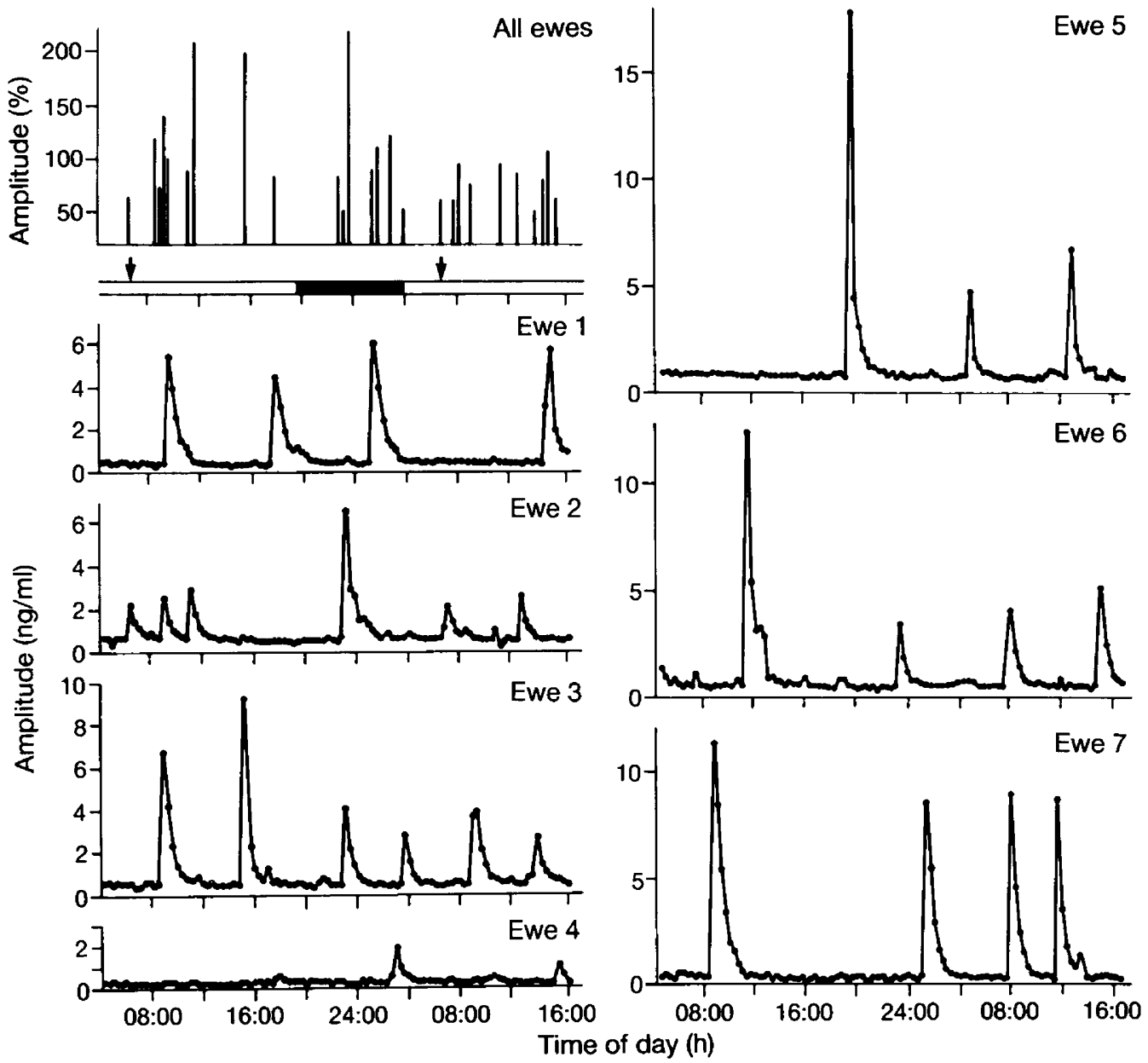

Text-fig. 2. LH pulse profiles of entire anoestrous Romanov ewes, from which blood was sampled every $20 \mathrm{~min}$ for $36 \mathrm{~h}$, demonstrating the grouping of pulses that leads to wide variation in pulse intervals. Note the change in the units on the $y$ axis from $\mathrm{ng} / \mathrm{ml}$ for individual ewes to percentage of mean amplitude for the combined profile. The arrows indicate time of food distribution. 


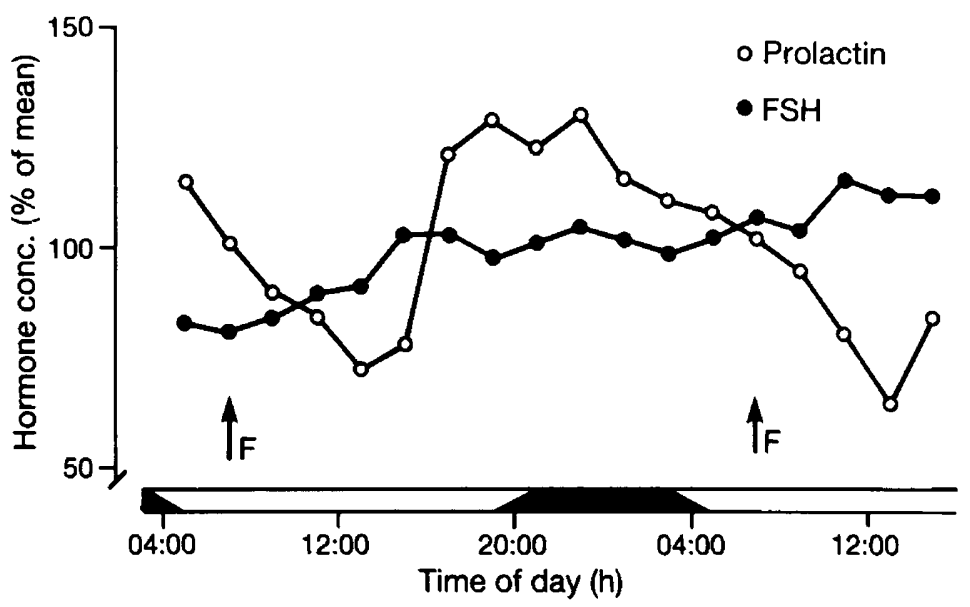

Text-fig. 3. Changes in the plasma concentrations of prolactin and FSH in entire anoestrous Romanov ewes sampled every $20 \mathrm{~min}$ over $36 \mathrm{~h}$. Each point represents data from 42 plasma samples ( 7 ewes, 6 samples), averaged and expressed as a percentage of the mean level of the individual ewe. The LSDs were $38.7 \%$ for prolactin and $15 \cdot 2 \%$ for FSH. The time of food distribution is indicated by $F$.

\section{Experiment 3}

Pulses of LH were evident in all ewes (Text-fig. 2) and, although the overall mean pulse interval $(472 \pm 46 \mathrm{~min})$ and amplitudes $(5.3 \pm 1.03 \mathrm{ng} / \mathrm{ml})$ were similar to those observed before the ram effect in Exp. 1, there was considerable variation both between and within animals. The within-ewe variation in pulse interval was due to a 'grouping' of the pulses so that a long interval was followed by a series of shorter intervals (Text-fig. 2). There did not appear to be any daily variation in either pulse amplitude or pulse interval, nor was there evidence of a more favoured period for the release of pulses. There was a significant $(P<0.025)$ effect of sampling time on the plasma concentrations of prolactin and when the means for each 2-h period were plotted (Text-fig. 3) the daily variation became evident. The highest values were observed during the night and the lowest during the day but the onsets of the rising and descending phases of the rhythm did not appear to coincide with solar dusk or dawn, or the feeding times. The prolactin concentrations for individual ewes varied between 88 and $213 \mathrm{ng} / \mathrm{ml}$. There was no significant diurnal rhythm in the FSH concentrations, which rose continuously throughout the course of sampling (Text-fig. 3).

\section{Discussion}

In the experiments described here, the pattern and timing of the endocrine and ovarian responses to the ram effect were similar to those observed in our earlier work with other breeds (Oldham, Martin \& Knight, 1978; Martin et al., 1980a; Poindron et al., 1980), but we have expanded upon our previous knowledge by demonstrating that the increase in LH pulse frequency induced by the rams is accompanied by a decrease in pulse amplitude, that the magnitude of the frequency increase determines whether the ewe will ovulate and that the LH response is far more rapid and the ovulation rate is higher if the rams are introduced in the morning rather than the evening.

The cause of the diurnal variation in responsiveness to the ram effect remains to be determined. The LH response could have the same origin in the central nervous system as the rhythms in melatonin, prolactin, growth hormone and corticosteroid, or it could be a consequence of these rhythms. With regard to the difference in ovulation rate between ewes in Groups AM and 
PM, it seems likely that the ovary is also following one of these endocrine rhythms because the ovulatory response to an injection of PMSG also depends on the time of day the injection is given (Cognie, Martinet \& Schirar, 1984). Which rhythm is involved is unknown, although the present experiments would suggest that it is not likely to be the gonadotrophins.

The timing of ram introduction had no effect on the delay to the LH surge or the onset of oestrus, or on the proportion of ewes responding, events which would be mediated by the effects of LH on follicular growth and steroid production. It therefore seems unlikely that delay to the first pulse is associated directly with subsequent effects on ovulation rate. Furthermore, given the low numbers of animals compatible with the protocols for Exps 1 and 2, and the use of different breeds, we must interpret the effect on ovulation rate and the association between the two effects cautiously.

Rhythms in the secretion of gonadotrophins have been reported for sheep maintained under artificial photoperiods. There is considerable disagreement in the literature regarding the timing of peak periods of secretion of LH pulses with Lincoln \& Peet (1977) and Lincoln et al. (1977) reporting fewer pulses in the morning than in the late afternoon in rams and Ortavant et al. (1982) obtaining clear statistical evidence that pulses were rare around dawn but most common only $3-4 \mathrm{~h}$ later. A third variation was provided by Walton et al. (1980) who observed a tendency for ewes to have a pulse in synchrony with 'dawn' and another in the late afternoon. With our data from ewes kept under natural photoperiod, we were unable to detect any significant diurnal variation and cannot support any of the previous observations. Furthermore, the 'grouping' of LH pulses (Text-fig. 2), a phenomenon which is probably a reflection of the dynamic nature of the negative feedback system (see p. 30 of Martin, 1984), could lead to chance observation of a 'favoured' period, especially with brief sampling periods. We therefore suggest that any temporal distribution in the secretion of a hormone released in pulses should be interpreted with caution.

A diurnal rhythm in the secretion of FSH, with a decline in levels in the morning followed by an increase in the evening, has also been observed in sheep (Lincoln \& Peet, 1977; Lincoln et al., 1977; Blanc et al., 1981). The profile we observed in Exp. 1 was strikingly similar to this and led us to attempt to verify it in Exp. 3, which was designed expressly for the detection of diurnal rhythms. We were unable to confirm its existence and suggest that further investigation is required.

The high nocturnal and low diurnal levels of prolactin observed in Exp. 3 are similar to the patterns seen previously in rams at Nouzilly (Ravault \& Ortavant, 1977) and in ewes in other laboratories (Davis \& Borger, 1974; Walton et al., 1980). However, there was considerably more variation in the timing and degree of expression of the rhythm in the present experiment than in the other studies. In most of the previous studies, the animals were maintained under artificial photoperiods in which dawn and dusk were abruptly and precisely determined by 'lights on' and 'lights off'. In the present experiment, carried out under natural lighting, dawn and dusk were detected by the ewes, suggesting that the rhythm may be best expressed only with abrupt changes in environmental lighting.

In the first study of the effect of the introduction of rams on the secretion of $\mathrm{LH}$, we suggested that the frequency of pulses before stimulation could determine the magnitude of the subsequent endocrine response and that this would then determine the ovarian responses (Martin et al., 1980a). The data from the present study do not support the first part of this hypothesis, but the difference in pulse frequency between ovulating and non-ovulating ewes does show that the pulse frequency which ultimately results from the ram effect is important in deciding whether the ewe will continue to follow the course of events leading to ovulation. This observation can be added to the growing body of evidence from experiments with exogenous $\mathrm{LH}$ or GnRH which show that ovarian function in the anoestrous ewe is limited primarily by the frequency of the endogenous LH pulses (McNeilly, O'Connell \& Baird, 1982; McLeod, Haresign \& Lamming, 1982).

Also for the first time, we report that a decrease in pulse amplitude accompanies the increase in pulse frequency induced by the introduction of rams. This effect on amplitude is similar to that observed in ewes following the transition from the luteal phase to the follicular phase during the 
breeding season (Baird, 1978; Thomas, 1983), and is either a direct consequence of the increase in pulse frequency (review: Martin, 1984), or an indirect consequence through a reduction of pituitary responsiveness to GnRH by oestradio: (Goodman \& Karsch, 1980) released in response to the high frequency of LH pulses (Scaramuzzi \& Baird, 1977).

Before the experiment described here, it was not known whether Romanov ewes would respond to the ram effect. In the original descriptions of the characteristics of the breed, published in Russia as early as 1802, it was claimed that the ewes could display oestrus at all times of the year (review: Desvignes, 1971). Our results suggest that these observations could be explained by the response of Romanov ewes to the ram effect. Furthermore, the ewes also maintain their high potential for multiple ovulation despite the inhibitory effects of the anoestrous season, as do Merino ewes immunized against androstenedione (Martin, Scaramuzzi \& Lindsay, 1981). Further investigation is warranted as the ram effect is potentially very useful in intensive breeding programmes (Marcus, Hackett \& Robertson, 1981; Martin \& Scaramuzzi, 1983) in which the more fecund breeds (such as the Romanov) perform best (Notter \& Copenhaver, 1980; Cornu \& Cognié, 1984).

\section{References}

Baird, D.T. (1978) Pulsatile secretion of LH and ovarian estradiol during the follicular phase of the sheep estrous cycle. Biol. Reprod. 18, 359-364.

Blanc, M.R. \& Poirier, J.C. (1979) A new homologous radioimmunoassay for ovine follicle stimulating hormone: development and characterization. Annls Biol. anim. Biochim. Biophys. 19, 1011-1026.

Blanc, M.R., Daveau, A., Ortavant, R., Pelletier, J., Ravault, J.P. \& de Reviers, M.M. (1981) Circadian variations of $\mathrm{LH}, \mathrm{FSH}$ and $\mathrm{Prl}$ in the Ile-de-France and Prealpes rams. In Photoperiodism and Reproduction in Vertebrates, pp. 99-115. Eds R. Ortavant, J. Pelletier \& J. P. Ravault. INRA Publications, Versailles.

Cognié, Y., Martinet, J. \& Schirar, A. (1984) Ovarian responses of seasonally anoestrous ewes to hormonal stimulation in the morning or the evening. Proc. 10th Int. Congr. Anim. Reprod. \& A.I. Champaign-Urbana, pp. 312-314.

Cornu, C. \& Cognié, Y. (1985) Utilization of Romanov sheep in a system of integrated husbandry. In The Genetics of Reproduction in Sheep, pp. 383-389. Eds R. B. Land \& D. W. Robinson. Butterworths, London.

Davis, S.L. \& Borger, M.L. (1974) Dynamic changes in plasma prolactin, luteinizing hormone and growth hormone in ovariectomized ewes. J. Anim. Sci. 38, $795-802$.

Desvignes, A. (1971) Revue bibliographique: la race ovine Romanov. Annls Zootech. 20, 353-370.

Fabre-Nys, C., Martin, G.B., Cognié, Y. \& Thiéry, J.-C. (1984) Onset of the preovulatory LH surge and of oestrous behaviour: night is a preferred period. Theriogenology 22, 489-495.

Fulkerson, W.J. \& Tang, B.Y. (1979) Ultradian and circadian rhythms in the plasma concentrations of cortisol in sheep. J. Endocr. 81, 135-141.

Goodman, R.L. \& Karsch, F.J. (1980) Pulsatile secretion of luteinizing hormone: differential suppression by ovarian steroids. Endocrinology 107, 1286-1290.

Kann, G. (1971) Dosage radioimmunologique de la prolactine plasmatique chez les ovins. $C$. r. hebd. Séanc. Acad. Sci. Paris D 272, 2808-2811.
Knight, T.W. (1983) Ram-induced stimulation of ovarian and oestrous activity in anoestrous ewes-a review. Proc. N.Z. Soc. Anim. Prod. 43, 7-11.

Lincoln, G.A. \& Peet, M.J. (1977) Photoperiodic control of gonadotrophin secretion in the ram: a detailed study of the temporal changes in plasma levels of follicle-stimulating hormone, luteinizing hormone and testosterone following an abrupt switch from long to short days. $J$. Endocr. 74, 355-367.

Lincoln, G.A., Peet, M.J. \& Cunningham, R.A. (1977) Seasonal and circadian changes in the episodic release of follicle-stimulating hormone, luteinizing hormone and testosterone in rams exposed to artificial photoperiods. J. Endocr. 72, 337-349.

McLeod, B.J., Haresign, W. \& Lamming, G.E. (1982) The induction of ovulation and luteal function in seasonally anoestrous ewes treated with small-dose multiple injections of GnRH. J. Reprod. Fert. 65, 215-221.

McNeilly, A.S., O'Connell, M. \& Baird, D.T. (1982) Induction of ovulation and normal luteal function by pulsed injections of luteinizing hormone in anestrous ewes. Endocrinology 110, 1292-1299.

Marcus, G.J., Hackett, A.J. \& Robertson, H.A. (1981) Ram-induced synchronization of estrus in confined ewes under controlled lighting. Can. J. Anim. Sci. 61, 833-837.

Martin, G.B. (1984) Factors affecting the secretion of luteinizing hormone in the ewe. Biol. Rev. 59, 1-86.

Martin, G.B. \& Scaramuzzi, R.J. (1983) The induction of ovulation in seasonally anovular ewes by exposure to rams. J. Steroid Biochem. 19, 869-875.

Martin, G.B., Oldham, C.M. \& Lindsay, D.R. (1980a) Increased plasma LH levels in seasonally anovular Merino ewes following the introduction of rams. Anim. Reprod. Sci. 3, 125-132.

Martin, G.B., Oldham, C.M. \& Lindsay, D.R. (1980b) Effect of stress due to laparoscopy on plasma cortisol levels, the preovulatory surge of LH and ovulation in the ewe. Theriogenology 16, 39-44.

Martin, G.B., Scaramuzzi, R.J. \& Henstridge, J.D. (1983) Effects of oestradiol, progesterone and androstenedione on the pulsatile secretion of luteiniz- 
ing hormone in ovariectomized ewes during spring and autumn. J. Endocr. 96, 181-193.

Martin, G.B., Scaramuzzi, R.J. \& Lindsay, D.R. (1981) Induction of ovulation in seasonally anovular ewes by the introduction of rams: effects of progesterone and active immunization against androstenedione. Aust. J. biol. Sci. 34, 569-575.

Notter, D.R. \& Copenhaver, J.S. (1980) Performance of Finnish Landrace crossbred ewes under accelerated lambing. I. Prolificity and ewe productivity. J. Anim. Sci. 51, 1033-1042.

Oldham, C.M. \& Lindsay, D.R. (1980) Laparoscopy in the ewe: a photographic record of the ovarian activity of ewes experiencing normal or abnormal oestrous cycles. Anim. Reprod. Sci. 3, 119-124.

Oldham, C.M., Martin, G.B. \& Knight, T.W. (1978) Stimulation of seasonally anovular Merino ewes by the introduction of rams. I. Time from the introduction of rams to the preovulatory LH surge and ovulation. Anim. Reprod. Sci. 1, 283-290.

Ortavant, R., Daveau, A., Garnier, D.H., Pelletier, J., de Reviers, M.M. \& Terqui, M. (1982) Diurnal variation in the release of $\mathbf{L H}$ and testosterone in the ram. $J$. Reprod. Fert. 64, 347-353.

Pelletier, J., Kann, J., Dolais, J. \& Rosselin, G. (1968) Dosage radioimmunologique de l'hormone luteinisante plasmatique chez le mouton. Mise au point de la technique de dosage. C. r. hebd. Séanc. Acad. Sci. Paris D 266, 2291-2294.

Poindron, P., Cognié, Y., Gayerie, F., Orgeur, P., Oldham, C.M. \& Ravault, J.P. (1980) Changes in gonadotrophins and prolactin levels in isolated (seasonally or lactationally) anovular ewes associated with ovulation caused by the introduction of rams. Physiol. Behav. 25, 227-236.
Ravault, J.P. \& Ortavant, R. (1977) Light control of prolactin secretion in sheep. Evidence for a photoinducible phase during a diurnal rhythm. Annls Biol. anim. Biochim. Biophys. 17, 459-473.

Rollag, M.D. \& Niswender, G.D. (1976) Radioimmunoassay of serum concentrations of metatonin in sheep exposed to different lighting regimens. Endocrinology 98, 482-489.

Scaramuzzi, R.J. \& Baird, D.T. (1977) Pulsatile release of luteinizing hormone and the secretion of ovarian steroids in sheep during anestrus. Endocrinology 101, 180I-1806.

Sokal, R.R. \& Rohlf, F.J. (1969) Biometry. Freeman, San Francisco.

Terqui, M. \& Thimonier, J. (1974) Nouvelle methode radioimmunologique rapide pour l'estimation du niveau de progesterone plasmatique. Application pour le diagnostic precoce de la gestation chez la brebis et la chevre. C. r. hebd. Séanc. Acad. Sci. Paris $D$ 279, 1109-1112.

Thomas, G.B. (1983) A study of the pulsatile secretion of luteinizing hormone in the Merino ewe. Proc. Aust. Soc. Reprod. Biol. 15, 47, Abstr.

Walton, J.S., Evins, J.D., Fitzgerald, B.P. \& Cunningham, F.J. (1980) Abrupt decrease in daylength and short-term changes in the plasma concentrations of FSH, LH and prolactin in anoestrous ewes. J. Reprod. Fert. 59, 165-171. 